\title{
Jan Hjarnø
}

\section{Indvandrere som}

\section{selverhvervende}

- en sammenlignende analyse af udbredelsen af selverhverv

\section{hos danske pakistanere, tyrkere og eksjugoslavere.}

Der er stor forskel $i$ andelen af selverhvervende i de forskellige indvandrergrupper, uanset at de har været lige længe $i$ indvandrerlandet og haft samme muligheder for at etablere sig. Årsagerne hertil søges afdækket ved at sammenligne de sociale og kulturelle baggrunde hos tre indvandrergrupper. Basis for komparationen er Højrups livsformshypotese. De empiriske vidnesbyrd indikerer, at de livsformer, indvandrere har med fra deres respektive oprindelseslande, spiller en afgorende rolle for om den enkelte vil søge at etablere sig som selverhvervende. 
$\mathrm{I}$ de gamle industrilande i Vesteuropa og Nordamerika etablerer mange indvandrere sig som selvstændige erhvervsdrivende. Mange har dokumenteret, at de er i stand til at klare sig selv, og nogle har opnået et højt velstandsniveau. Fremkomsten af dette borgerskab af selvstændige erhvervsdrivende indvandrere står i skarp kontrast til det generelle billede mange har af indvandrere som en marginaliseret gruppe, der selv i økonomiske opgangstider har vanskeligt ved at få arbejde.

Hermed er ikke sagt, at alt er guld og grønne skove. Langt fra alle har formået at skabe sig en økonomisk sikker eksistens. Ressourcer i form af kapital og viden er i mange tilfælde begrænsede. Mange må derfor gå ind i brancher, hvor kravene til kapital og viden er mindst, konkurrencen derfor særlig hård og mulighederne for profit små. Trods lange arbejdstider og gratis assistance fra familie og venner har en del svært ved at klare sig. Hvad angår ansatte, lever løn- og arbejdsforhold ikke altid op til standarden på det øvrige arbejdsmarked. I bestræbelserne på at overleve fristes nogle til ulovlig virksomhed i form af unddragelse af skatter og afgifter, beskæftigelse af personer på overførselsindkomst eller af personer uden arbejdstilladelse. Herved kommer nogle i konflikt med myndighederne og kommer i mediernes søgelys, hvilket kan fremkalde et generelt negativt billede af selverhvervende indvandrere som snydere og bedragere. Indvandrere i selverhverv rummer såvel en solsom en skyggeside.

Også Danmark har oplevet, at indvandrere bliver selverhvervende. Andelen af selverhvervende er imidlertid meget forskellig fra nationalitet til nationalitet, selv for nationaliteter der har været lige længe i Danmark og haft samme muligheder for at etablere sig set i forhold til det danske samfund. Disse forskelle re- præsenterer et forklaringsproblem, idet man må antage, at når et indvandrerland giver indvandrere samme muligheder for at etablere sig som selverhvervende, må man, alt andet lige, forvente, at andelen af selverhvervende ville være ens i de forskellige nationaliteter. Når det ikke er tilfældet, må man formode, at forklaringen på de observerede forskelle må søges i det forhold, at grupper har forskellig social og kulturel baggrund ${ }^{1}$. En komparativ analyse af gruppernes sociale og kulturelle baggrunde må derfor formodes at kunne afdække eventuelle ligheder og forskelle og give mulighed for en indkredsning af de faktorer, der spiller en afgørende rolle for observerede forskelle.

\section{Teoretisk udgangspunkt}

En produktiv komparativ analyse forudsætter en robust hypotese. Den foreliggende problemstilling er ikke ny. Sociologer i USA og England har for mange år siden bemærket, at andelen af selverhvervende kan være meget forskellig i forskellige nationalitetsgrupper af indvandrere. I slutningen af 1980erne samledes et konsortium (kendt som Waldinger-konsortiet) for at udvikle en teori, der kunne forklare forskellene (Waldinger, Aldrich, Ward and Associates 1990). Den forklaringsmodel, man kom frem til, var, at hyppigheden $i$ antallet af selverhvervende $i$ en specifik nationalitetsgruppe i første række var et produkt af en specifik kulturel arv. Indvandrernationaliteter, hvor en stor andel af medlemmerne havde traditioner for selverhverv $i$ hjemlandet, havde også en høj andel af selverhvervende i indvandrerlandet. Inspireret af en ældre artikel af Bonacich (1973) valgte man at klassificerede sådanne nationalitetsgrupper "middleman minorities".

Men man var ikke tilfreds. Teorien var utilstrækkelig. Indvandring i sig selv kunne nemlig skabe et specifikt behov 
efter varer fra en indvandrergruppes oprindelsesland, og en sådan efterspørgsel kunne føre til, at medlemmer i en sådan gruppe, som ikke nødvendigvis havde traditioner som selverhvervende med fra hjemlandet, etablerede sig som selverhvervende for at opfylde behovet. Hermed fødtes den "etniske enklaveøkonomiteori".

Konsortiet giver ikke nogen præcis sociologisk forklaring på, hvorfor indvandrere med tradition for selverhverv $i$ hjemlandet vælger at blive selverhvervende i det fremmede. Men formodentlig bygger denne delteori implicit på en antagelse om, at mennesker generelt altid vil søge at videreføre deres traditioner, hvis de har mulighed for det. Heller ikke den anden delteori specificeres, men hviler formodentlig implicit på en generel antagelse om, at et behov for bestemte typer af varer altid vil blive tilfredsstillet ved, at nogle bliver selverhvervende for at tilfredsstille behovet, uden at de har traditioner for at være selverhvervende med fra hjemlandet. Der er en vis modsigelse mellem de to delteorier, fordi man fx ikke forklarer, hvad der helt specifikt skal til for, at individer, der ikke har tradition for at være selverhvervende, motiveres (eller måske snarere tvinges) til at blive selverhvervende ${ }^{2}$.

Konsortiet mener imidlertid, at den faktor, der spiller den afgørende rolle for fremkomsten af selverhvervende $\mathrm{i}$ indvandrergrupper, er de økonomiske og institutionelle forhold $\mathrm{i}$ indvandrersamfundet. Hvis ikke der er, hvad man kalder en "opportunity structure", dvs. en struktur der tillader, at indvandrere etablerer sig som selverhvervende, fremkommer der ingen selverhvervende. Det er uomtvisteligt korrekt, men argumentet fører konsortiet ind i en blindgyde, idet man bruger mange kræfter på at beskrive, hvad en sådan "the opportunity structure" kan omfatte. Konsortiets teoretise-

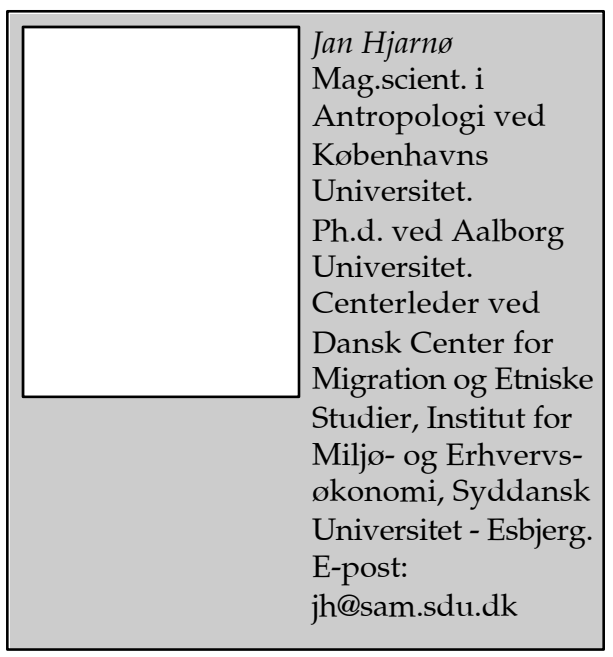

ring har påkaldt sig kritik, men ingen af kritikerne, bortset fra Louise Hardman Smidt (der skriver på dansk), har forsøgt at opstille en modteori (Bonacich 1993; Light \& Bonacich 1998; Light \& Rosenstein 1995; Morokvasic 1993; Phizacklea 1990, Rath 1999; Smidt 1996). Konsortiets teorier er utilfredsstillende. Jeg er enig i konsortiets grundantagelse af, at al social og kulturel adfærd er motiveret. De mener nemlig, at når indvandrere etablerer sig som selverhvervende, er det enten motiveret af, at de har tradition for at være selverhvervende i deres hjemland, eller af at indvandringen har skabt en efterspørgsel, som får nogle til at etablere sig som selverhvervende, uanset om de har medbragt en tradition for at være selverhvervende i hjemlandet. Jeg savner imidlertid en uddybende begrundelse af det sidstnævnte.

At muligheder for praksis af en bestemt social adfærd er til stede i et samfund, er i sig selv ikke tilstrækkelig til, at der nødvendigvis artikuleres en sådan adfærd. Der skal være forudsætninger til stede for, at mennesker får øje på mulighederne og handler på dem. Jeg er således enig med Jonathan Friedman, når han hævder: 
Al kulturel skabelse er motiveret. Og motiverne findes inden for de skabende subjekters kontemporære eksistens. Innovation er således funderet i historiske omstændigheder og nødvendigvis i en social og eksistentiel kontinuitet (Friedman 1994:13).

Mennesker, der handler i nutiden, er født i fortiden. De er født ind i forskellige sociale og kulturelle miljøer, som har påvirket dem gennem deres barndom, ungdom og som voksne. Gennem deres forældre, søskende og andre nære slægtninge og venner er ethvert individ blev opdraget til at forstå, hvad man i vedkommendes opvækstmiljø opfatter som rigtigt og forkert, og hvad der er den rette måde at leve på. Gennem socialiseringen har individet umærkeligt lært at opfatte sin måde at leve på eller det ideal, der stræbes mod, som naturlig og rigtig. Det har påvirket vedkommendes bevidsthed og måder at tænke på. Individet opfatter sine erfaringer som den "objektive sandhed" og ikke som noget, der er dannet af vedkommendes egen opfattelse af verden, dvs. vedkommendes ideologi. Som Højrup har sagt, er ideologien usynlig, men til trods for det en magtfuld faktor i menneskers livsform. Alle er knyttet til en specifik livsform uafhængig af deres egen vilje. Hvad individer ønsker er bestemt af deres kultur (Højrup 1983:21). Højrup ligger her på linie med en aktuel og central sociologisk tankegang:

Betingelserne knyttet til en bestemt klasse af eksistensbetingelser producerer habitus, systemer af holdbare, omflyttelige bestemmelser, strukturerede strukturer prædisponerede til at fungere som strukturerende strukturer, dvs. som principper, der skaber og organiserer praksis og repræsenta- tioner, der kan være objektivt tilpasset til deres resultater uden bevidst at være rettet mod mål af nogen klar beherskelse af de processer, der er nødvendige (.....) for at opnå dem. Objektivt "reguleret" og "regelmæssig" uden på nogen måde at være produkterne af lydighed over for regler, de kan være kollektivt samordnet uden at være resultatet af en leders organiserende påvirkning. Naturligvis er det aldrig udelukket, at habitusens reaktioner kan være ledsaget af en strategisk beregning, der har tendens til på en bevidst måde at udføre den operation, at habitusen opfører sig helt forskelligt, nemlig et skøn af muligheder, der forudsætter, at den tidligere effekt omdannes til et forventet mål? (Bourdieu 1990: 53).

Det normale er således, at sociale aktører søger at bibeholde deres livsform eller habitus. Hvis eksistensbetingelserne, som danner grundlag for et individs livsform, forsvinder, vil det søge efter alternative eksistensbetingelser, som gør det muligt at videreføre livsformen. Hvis der ikke findes sådanne alternativer, vil den normative struktur, habitusen, der er knyttet til det oprindelige livsmønster, gradvist forsvinde og blive erstattet med en ny normativ struktur, en ny habitus, som på afgørende vis vil komme til at præge de børn, der vokser op under de nye eksistensbetingelser.

Konsortiets og dets kritikere, bortset fra Louise Hardtman Schmidt, har savnet en teori, der kan forklare, hvorledes mennesker søger at organisere deres liv i forhold til de eksisterende erhvervsmuligheder, når man kender deres baggrund. Højrups livsformshypotese fra 1983 er i denne sammenhæng brugbar, idet den siger, at måden, hvorpå menne- 
sker er tilknyttet produktionen, vil præge deres normer, værdier, begrebsopfattelse, sprog og den måde, hvorpå de vil forsøge at organisere deres liv. På det generelle plan er der intet nyt i denne antagelse, idet strukturel sociologi altid har set på værdier og normer under betingelse af givne levekår. Højrups livsformshypotese går imidlertid et lille skridt videre, idet den gennem en præcis definering af de specifikke produktionsstrukturer, der forekommer i et konkret samfund, åbner op for en identificering af en række specifikke livsformer, der, hvad angår normer, værdier, idealer og motivationsmønstre, kan have et vidt forskelligt indhold. Produktionsstrukturer som den kapitalistiske produktionsform og den simple vareproduktionsform har vid udbredelse globalt, og de livsformer, der er knyttet til disse produktionsformer, er identiske uanset, hvilket land man kommer fra ${ }^{3}$. Derfor er livsformshypotesen et velegnet instrument til på tværs af nationale, religiøse og etniske skillelinier at sammenligne forskellige befolkningsgruppers sociale handlemønstre i forhold til bl.a. valg af erhvervsmæssig beskæftigelse.

Den simple vareproduktionform danner eksistensgrundlag for én enkelt livsform, "den selverhvervende livsform", hvis mål er at opretholde en "fri“" tilværelse som selvstændig (Højrup 1983; 1989). Den kapitalistiske produktionsform er defineret ved, at en gruppe sociale aktører ejer produktionsmidlerne og råvarerne, mens en anden gruppe deltager i produktionen ved at sælge deres arbejdskraft til medlemmer i den førstnævnte gruppe. Her er tale om to klasser. Varer og tjenesteydelser, som resulterer af produktionen, tilfalder arbejdsgiveren, hvis motiver til at sætte produktionen i gang ifølge definitionen er at sikre sig et økonomisk overskud. Den kapitalistiske produktionsform danner således eksistens- grundlag for en kapitalejerlivsform eller som Højrup siger "den borgerlige livsform", såvel som for to forskellige typer af lønmodtagerlivsformer (Højrup 1983). Sidstnævnte artikuleres, fordi der har udviklet sig et behov for to typer af arbejdskraft: En, der kan udføre de styrende, udviklende og administrative funktioner med høje krav til arbejdskraftens uddannelsesmæssige kvalifikationer og en, der kan udføre de manuelt og rutineprægede arbejdsfunktioner, hvor kravene til arbejdskraftens uddannelsesmæssige kvalifikationer er beskedne. Processen går i retning af to forskellige livsformer, en karrierelivsform, hvor målet er at gøre karriere, og en lønarbejderslivsform, hvor målet er at tilvejebringe en lønindtægt, som sætter aktøren i stand til at realisere sig selv i sin fritid (Højrup 1983; Hjarnø 2000).

Livsformshypotesen forklarer, at hvis mulighederne for selverhverv er til stede $i$ et samfund, vil erhvervsaktive indvandrere, der er præget af den selverhvervende livsform, forsøge at etablere sig som selverhvervende. Individer præget af lønarbejderlivsformen vil søge at videreføre deres livsform, og individer med en karrierebetonet livsform vil søge et karrierearbejde. Her er tale om idealtyper. I den empiriske verden må der forventes bløde overgange mellem typerne. Hypotesens holdbarhed vil afhænge af, om det er muligt empirisk at dokumentere en sammenhæng mellem indvandreres opvækstmiljøs placering erhvervsmæssigt og deres erhvervsmæssige placering i indvandrerlandet.

\section{Metoder}

Til afprøvning af livsformshypotesen har jeg valgt at sammenligne tre nationalitetsgrupper i Danmark, nemlig indvandrerne fra Pakistan, Tyrkiet og det tidligere Jugoslavien. Jeg har valgt dem, fordi de kom til Danmark samtidig i slutnin- 
gen af 1960erne 4 . Gennem 30 år har de set i forhold til det danske samfund haft samme muligheder for at integrere sig. Forskelle i de tre gruppers integrationsmønstre, i dette tilfælde deres etablering som selverhvervende, må derfor formodes at være betinget af forskelle i deres sociale og kulturelle baggrunde.

Mit datagrundlaget er primært blevet tilvejebragt gennem de samtaler, jeg siden 1969 har haft med medlemmer fra de tre grupper. Mine vigtigste informanter er ikke blevet udvalgt efter repræsentativitetskriterier, der er typiske for de gængse formalistiske sociologiske undersøgelsesmetoder. Flertallet har valgt sig selv som mine informanter ved at opsøge mig. Nogle er kommet for at få hjælp til løsning af et eller andet praktisk problem, andre fordi de havde hørt, at jeg var til at tale med. Gennem de mange samtaler har jeg dannet mig et billede af udviklingen i grupperne. I visse tilfælde har det været muligt at sammenholde billedet med fx kvantitative data offentliggjort af Danmarks Statistik o.l. lignende institutioner, ligesom jeg også undertiden har kunnet drage sammenligninger med andre forskeres arbejder. Ofte har disse sammenligninger bekræftet mit billede. I tilfælde, hvor der har været uoverensstemmelse, har jeg søgt at få afklaret problemet gennem nye samtaler. De fleste samtaler er blevet ført i Danmark, men jeg har ved flere lejligheder været i Tyrkiet (Hjarnø 1971; 1988; 1991) og en enkelt gang i Makedonien. Jeg har i visse tilfælde søgt at supplere informationerne fra mine samtaler ved at benytte nogle formelle sociologiske teknikker, som $\mathrm{fx}$ individbaserede spørgeskemaer, fokusgruppeinterview, men det er samtalerne, der har givet mig indblik i de følsomme emner, som andre metoder ikke kan få frem ${ }^{5}$.

I den følgende sammenlignende beskrivelse og analyse har jeg valgt at fokusere på en afdækning af de erhvervs- strukturelle årsager til udvandringen i de tre nationalitetsgrupper i deres respektive hjemlande. Indvandrernes erhvervsmæssige forankring i disse strukturer har præget den livsform eller med en Bourdieusk term, den habitus, de møder op med i indvandrerlandet, og som i dette tilfælde er Danmark. I tilknytning hertil har jeg også ment det vigtigt at få belyst rekrutteringen, dvs. hvad slags individer (forstået som specifikke bærere af bestemte livsformer) indvandrerne er.

\section{De sociale og kulturelle baggrunde}

Motivationen for at tage til Danmark har for flertallets vedkommende i alle tre grupper været at tjene penge og spare op, så man kunne vende hjem til en forhåbentlig økonomisk tryggere fremtid. Årsagen til, at de kunne komme og arbejde i Danmark var, at Danmark i slutningen af 1960erne manglede arbejdskraft. Danmark havde fuld beskæftigelse. For at forhindre, at danske virksomheder blevet tvunget til at lukke eller flytte til udlandet på grund af mangel på arbejdskraft, besluttede regeringen i 1967, at udlændinge kunne få opholds- og arbejdstilladelse, hvis de kunne finde en ledig stilling, som det ikke var muligt at besætte med dansk arbejdskraft. Det resulterede $i$ en accelererende tilstrømning af arbejdssøgende udlændinge. Af frygt for, at antallet af arbejdssøgende skulle overstige behovet for arbejdskraft, besluttede politikerne i november 1970 at indføre et midlertidigt stop for udstedelse af nye førstegangsarbejdstilladelser. Dette stop har været i kraft siden bortset fra nogle få måneder i 1973. Det har imidlertid været muligt for personer med permanent opholdstilladelse i Danmark at få tilladelse til familiesammenføring, og dette har resulteret $i$ en betydelig indvandring ${ }^{6}$. Disse pårørende er kommet fra de samme miljøer, som de, der indvandre- 
de, mens Danmark var åbent for import af arbejdskraft, og har således samme sociale og kulturelle baggrund.

Mens Danmark var åbent for import af arbejdskraft, fik de udenlandske arbejdssøgende hovedsagelig ansættelse $\mathrm{i}$ konkurrencesvage virksomheder, som ikke kunne tiltrække tilstrækkelig arbejdskraft af dansk oprindelse, fordi løn og ansættelsesvilkår ikke var attraktive nok. I nogle år bidrog udlændingene til at forlænge solnedgangen over disse virksomheder, men på grund af konkurrencen fra lande med løn- og arbejdsvilkår, som Danmark ikke kunne konkurrere med, forsvandt mange af disse virksomheder i begyndelsen af 1970erne eller fortsatte i en gennemrationaliseret form, hvor der ikke var brug for så megen arbejdskraft. Mange blev arbejdsløse, men da de fleste havde opholdt sig over to år i Danmark og fået tildelt permanent opholdstilladelse, var de ikke tvunget til at rejse hjem, hvis de økonomisk var i stand til at klare sig selv. Det var flertallet, fordi de havde sørget for, at blive medlem af en arbejdsløshedskasse ${ }^{7}$. For de der blev, var det økonomisk set mere rationelt at leve af dagpenge og søge ny beskæftigelse i Danmark frem for at vende hjem. Men det var svært at finde nyt arbejde. Der var også stor arbejdsløshed blandt danskerne, og danske arbejdspladser foretrak i vid udstrækning at ansætte danskere frem for personer af udenlandsk oprindelse (Arbejdsmarkedsstyrelsen 1993; Hjarnø og Jensen 1997).

Udviklingen, som i begyndelsen af 1970erne resulterede i en lang periode med høj arbejdsløshed, ændrede på afgørende vis erhvervsstrukturen i Danmark på samme måde, som det også skete samtidig i de fleste andre industrilande i Vesteuropa og Nordamerika. Det manuelle og ikke særligt kvalifikationskrævende industriarbejde forsvandt for ofte at dukke op som nye arbejdspladser i de såkaldte nyindustrialiserede lande. De arbejdsfunktioner, der stillede store krav til medarbejdernes uddannelsesmæssige kvalifikationer, blev bibeholdt og udvidet. Det har i alle de gamle højtindustrialiserede lande, Danmark inklusiv, resulteret i en vækst i beskæftigelsen inden for erhvervsservice (Sassen 1991; Hjarnø 1996; 2001). Denne vækst har affødt en øget efterspørgsel efter en række andre servicebetonede arbejdsfunktioner, som ikke stiller høje uddannelsesmæssige kvalifikationskrav til udøverne. De gamle urbane industricentre, som $\mathrm{fx}$. København, er i dag blevet til erhvervsservicecentre, hvilket er en ny form for urban centerdannelse, som Saskiya Sassen har givet navnet "The Global City" (Sassen 1991, 1994; Hjarnø 1996). En lang række af de nye beskæftigelsesmuligheder inden for handel, service og transport stiller ofte ikke større kvalifikationsmæssige krav til udøverne, end at mennesker med en beskeden formel skoleuddannelse kan klare opgaverne. Er en udøvers personlige kvalifikationer ikke tilstrækkelige, har vedkommende i reglen muligheder for at købe den fornødne ekspertise. At drive forretning som vognmand, restauratør eller kolonialhandler kræver, at man er økonomisk indstillet, at man forstår at sætte næring efter tæring, men ikke, at man er fagkyndig i bogholderi og revision ${ }^{8}$.

Foruden, at de strukturelle forandringer har skabt nye muligheder for iværksættere, har man i Danmark fra politisk hold specifikt søgt at fremme iværksætteriet, ved bl.a. at tilbyde dagpengemodtagere mulighed for at få en iværksætterydelse (Dokumentation om indvandrere, $\mathrm{nr}$. 1:38, 1997). Nogle dagpengemodtagere, danskere såvel som personer af udenlandsk oprindelse, har taget imod disse tilbud, men det er langtfra alle iværksættere med en udenlandsk oprindelse, der 
har haft mulighed for at få iværksætterydelse, og blandt sidstnævnte har der været betydelig kritik af ydelserne, som man fandt var konkurrenceforvridende.

Min interesse for iværksætteriet blandt indvandrere startede for alvor $i$ begyndelsen af 1980erne, hvor jeg blev klar over, at pakistanerne i stigende grad begyndte at starte op som selverhvervende i Danmark. Jeg havde ganske vist mødt og talt med enkelte selverhvervende pakistanere tidligere, men havde betragtet dem som "enlige svaler", fordi fokus i mine samtaler med pakistanere på daværende tidspunkt mest drejede sig om, hvad de skulle lave, når de tog hjem. Jeg fik talrige oplysninger om, hvordan de sendte deres opsparinger hjem til Pakistan, hvordan de blev brugt til at forbedre deres boligforhold eller til at få gang i en virksomhed, som de satte slægtninge og venner i Pakistan til at passe. I begyndelsen af 1980erne blev mine samtalepartnere gradvis mere og mere optaget af spørgsmål som: Hvem har startet sin egen virksomhed. Hvordan kan man eventuelt få etableret sig som selvstændig i Danmark? Hvilke muligheder var der? Hvordan passede de med de kvalifikationer, man var i besiddelse af? Det blev prestigefuldt til at være selvstændig i Danmark, og det er det for øvrigt fortsat.

Blandt indvandrerne fra Tyrkiet var flertallet i begyndelsen af 1980erne stadig optaget af at skabe forudsætninger for en hjemvenden til Tyrkiet. De investerede i nye boliger i Tyrkiet og købte landbrugsmaskiner, som kunne lette landbrugsarbejdet, når de kom hjem. Nogle startede butikker, som de fik slægtninge til at passe, eller handlede med brugte lastbiler og traktorer, som de købte i Danmark og solgte videre i Tyrkiet. Nogle investerede i boligbyggeri med henblik på salg og udlejning. Interessen for at etablere sig som selvstændig i Danmark var begrænset, men i løbet af 1980erne ændrede billedet sig. Flere og flere erkendte, at drømmen om at vende hjem var en myte. Flere og flere fik egen virksomhed i Danmark, og det blevet prestigefuldt at vise, at man kunne klare sig selv i Danmark og ikke havde nogen overordnet.

I de samtaler, jeg har ført med indvandrerne fra det tidligere Jugoslavien, har flertallet aldrig været optaget af at tale om at blive iværksættere. De har derimod talt meget om, hvordan de har investeret deres opsparinger i forbedringer af deres boligforhold i Makedonien, Serbien og Kosovo, så de havde gode forhold at vende hjem til, og jeg har set talrige fotografier af deres nybyggede huse og fået opremsninger af alle de flotte moderne hvidevarer, store tv-apparater o.l., de var blevet udstyret med. Under mit besøg i Makedonien fik jeg ved selvsyn bekræftet, at oplysningerne var korrekte.

Det billede, der gradvist tegnede sig, på grundlag af mine mange samtaler med medlemmer i de tre grupper, kunne efterhånden bekræftes i de tal for andelen af selverhvervende i de tre grupper, som blev offentliggjort af Danmarks Statistik. Et eksempel på disse tal er vist $\mathrm{i}$ Figur 1, som er en årlig opgørelse af den procentvise andel af selverhvervende blandt de erhvervsaktive fordelt efter statsborgerskab i de fire grupper af statsborgere fra henholdsvis Danmark, Tyrkiet, Pakistan og det tidligere Jugoslavien i perioden 1980-1996. Figuren bekræfter det billede, jeg havde dannet mig: allerede omkring 1980 er pakistanske statsborgere begyndt at etablere sig som selverhvervende. Andelen vokser år for år frem til midten af 1990erne. Også de tyrkiske statsborgere oplever en vækst i andelen af selverhvervende. Talmæssigt er de dog ikke på højde med pakistanerne, men væksten er ikke ophørt. Hvad indvandrerne fra det tidligere Jugoslavien 
angår, er andelen af de, der har etableret sig som selverhvervende i Danmark, meget lille og meget lavere end blandt danske statsborgere ${ }^{9}$.

\section{Pakistanernes baggrund}

Dansk forskning i de pakistanske indvandreres sociale og kulturelle baggrund har været meget beskeden (Gudmundsson \& Holten 1976; Bajaj \& Laursen 1988; Elverdam 1991; Just Jeppesen 1989). Hovedparten stammer fra provinsen Punjab i Pakistan. De kommer fra landsbyer, hvor landbrug var det bærende erhverv, og hvor befolkningen er delt $i$ to hovedkaster, den jordejende kaste (zamindar) og den ikke jordejende kaste (kami). Medlemmer i den ikke jordejende kaste ernærede sig dels ved at udføre landbrugsarbejde eller forskelligt håndværksarbejde for medlemmer i den jordejende kaste. Der var et traditionelt kontraktforhold mellem jordejere og ikke jordejere omkring fordeling af arbejde og udbytte (Aase 1983: 38-39; 1991: 78). På grund af naturlig tilvækst i befolkning siden afslutningen af Anden Verdenskrig er jord blevet en utilstrækkelig ressource, og der har ikke med tilstrækkelig hast udviklet sig alternative erhvervsmuligheder. Der er et overudbud af arbejdskraft i systemet, og motivationen til at udvandre har været stor. Det er dog hovedsageligt blandt medlemmerne af den jordejende kaste, at man har kunnet rejse den fornødne kapital til udvandring.

Allerede i slutningen af 1950erne startede udvandringen til Storbritannien (Anwar 1996). Gradvist blev der indført restriktioner for indvandring og en del pakistanere søgte at finde alternative muligheder for udvandring. I slutningen af 1960erne fik nogle øje på muligheder i Holland og Danmark. Hurtigt kom der gang i kædevandringer fra de pågældendes landsbyer i Pakistan. I november 1970 lukkede Danmark for udstedelse af nye førstegangsarbejdstilladelser. I forbindelse med Danmarks indtræden i EF i 1973 kom en del engelske statsborgere af pakistansk oprindelse til Danmark for at arbejde og være sammen med deres herboende slægtninge og venner (Bajaj \& Laursen 1988:11-12).

Figur 1. Den procentvise andel af selverhvervende blandt de aktive på arbejdsmarkedet fordelt efter statsborgerskab, Tyrkiet, Pakistan, det tidligere Jugoslavien.

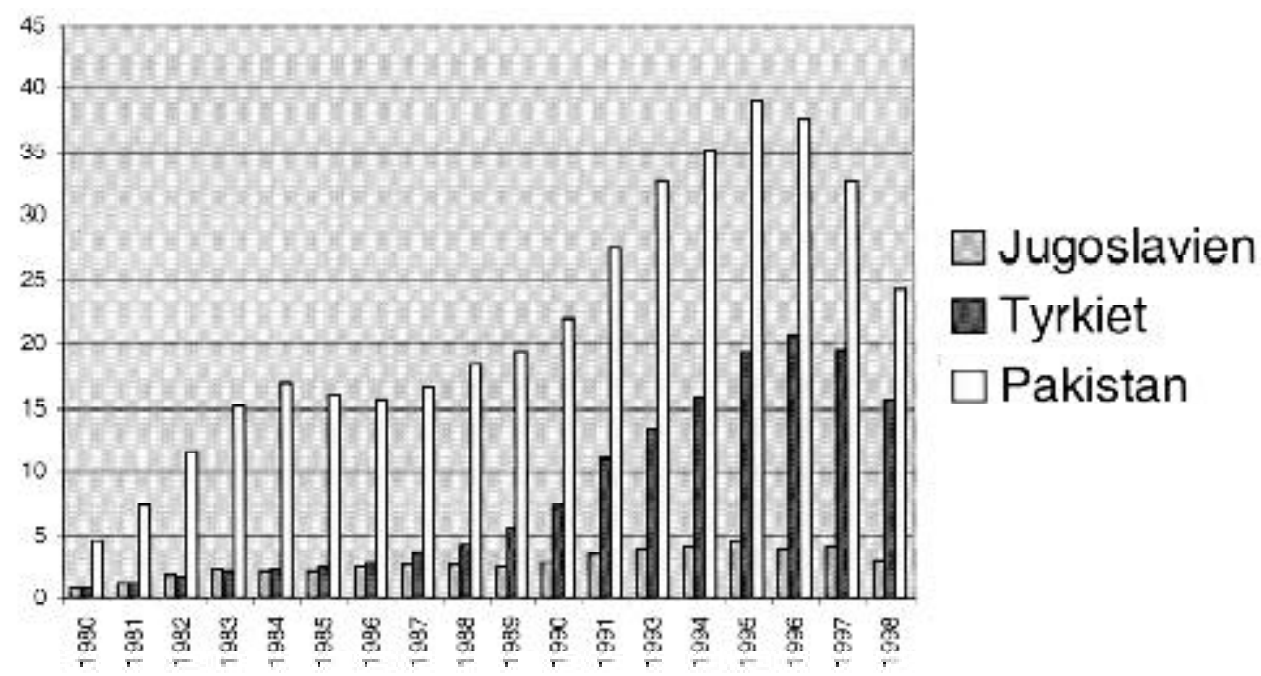


I starten var det fortrinsvis mænd, der kom og tog arbejde i dansk industri. De erkendte hurtigt, at det var kostbart at holde kontakt med ægtefælle og børn i hjemlandet, og at det økonomisk set var rationelt at tage kone og børn med til Danmark. Allerede i begyndelsen af 1970erne begyndte de en familiesammenføring. Pakistanernes boligforhold var på daværende tidspunkt generelt dårlige. For at kunne spare op søgte mange at holde deres udgifter til bolig så lave som mulig, men disse boliger egnede sig ikke til en større familie med børn. I 1972 indførte regeringen derfor det krav, at personer, der søgte tilladelse til familiesammenføring, skulle råde over "en passende bolig" ${ }^{\prime 10}$.

Dette krav var svært at opfylde i det gamle billige udlejningsbyggeri. For at få tilladelse til familiesammenføring lejede mange pakistanere sig ind i de nye, tomme og meget dyre almennyttige lejeboliger. De var opstået, fordi en række almennyttige boligselskaber havde opført flere dyre boliger, end der på daværende tidspunkt var behov for. Hurtigt erkendte mange pakistanere, at det økonomisk var mere rationelt at få sig en ejerbolig. Det var relativt let at få et banklån til udbetalingen. Udgifter til renter og afdrag var på 10-12\% af købsprisen og svarede ofte til den husleje, man betalte. Samtidig steg værdien af privatejede boliger ca. 20\% om året. Der var en inflationsgevinst ved at skifte fra lejebolig til ejerbolig. Relativt mange pakistanere fik ejerbolig (Hjarnø 1997: 78-90). Dette valg har haft en række konsekvenser (Hjarnø 1998). Kun en enkelt skal nævnes, og det er den friværdi, der opstod som følge af den høje inflation.

Pakistanernes mål med familiesammenføringerne i begyndelsen af 1970erne var ikke at blive fastboende i Danmark, men at øge mulighederne for at spare op, således at man i løbet af få år kunne vende hjem til Pakistan og etablere sig som selverhvervende. Af mange grunde blev det svært at realisere denne drøm. Derfor blev flertallet i Danmark, og efterhånden fik en del beskæftigelse i service- og transportsektoren. Det var bl.a. rengøring af butiks- og kontorlokaler og arbejde som taxi- eller buschauffør. Løn- og arbejdsmæssigt var det ikke de mest attraktive jobs, men bl.a. arbejdet som taxichauffør dannede senere forudsætning for, at flere og flere erhvervede sig den anciennitet, der var nødvendig for at få en vognmandsbevilling.

I takt med, at drømmen om en snarlig hjemvenden blev udskudt, voksede interessen for at realisere livsmålet ved at blive selvstændig i Danmark. De første pakistanskejede butikker dukkede op i slutningen af 1970erne. Det var kiosker, rejsebureauer og butikker, der solgte varer og serviceydelser, som var efterspurgte blandt de pakistanske indvandrere. I transportsektoren fik de pakistanske taxichauffører omtrent samtidig mulighed for at etablere sig som taxivognmænd. En større vognmand i København ønskede på grund af alder at afhænde sin virksomhed. Det var en for køberen relativt kapitalkrævende handel, og blandt interesserede danske vognmænd var der en vis tilbageholdenhed. En dansk vognmand har oplyst, at man håbede, at man ved at trække handlen i langdrag kunne opnå at få trykket prisen. Pludselig erfarede man, at virksomheden var solgt til en gruppe pakistanere og til den pris, som vognmanden havde forlangt. Handelen gav pakistanerne et godt fodfæste som vognmænd i den københavnske taxabranche og motiverede andre pakistanere til at etablere sig.

Kapitalen til investering i egne virksomheder kom fra flere kilder. Udgangspunktet var ofte en personlig opsparing suppleret med lån i realkreditinstitutter eller banker. Som garanti for lånene be- 
nyttede man dels værdien i virksomheden og dels friværdien i privatejede boliger. Det kunne være en bolig, som køberen ejede, men det kunne også være en bolig, der tilhørte en kautionist. Mit interviewmateriale viser, at man ofte har benyttet kautionister, og at der altid er en tæt slægtsmæssig forbindelse mellem kautionist og låntager. Det er normalt personer, der tilhører samme traditionelle broderskab (bradri) (Aase 1983: 44; 1991: 78). Den oparbejdede friværdi i ejerboligerne blev en vigtig løftestang, som sikrede og stadig sikrer kapital til etablering af selvstændige virksomheder. I det omfang, det har været muligt, har nogle forsøgt at benytte sig af tilbud om iværksætterydelse, men langtfra alle har haft denne mulighed, og der er ikke så stor prestige knyttet til at være hjulpet i gang med iværksætterydelse, som det er at kunne klare sig selv.

Selverhvervende mænd af pakistansk oprindelse havde i 1996 en gennemsnitlig skattepligtig bruttoindkomst på 540.000 kr., mens den tilsvarende bruttoindkomst for selverhvervende mænd af dansk oprindelse var 858.000 kr. (Hjarnø 2000).

\section{De tyrkiske \\ indvandreres baggrund}

Indvandringen af arbejdskraft fra Tyrkiet minder meget om indvandringen fra $\mathrm{Pa}$ kistan. I 1967 blev Vesttyskland ramt af en kortvarig økonomisk krise. I stedet for at vende hjem, forsøgte nogle udlændinge at finde arbejde i tilstødende lande. Herved kom de første arbejdere af tyrkisk oprindelse til Danmark. Der var tale om små grupper på 3-4 mand, som kom fra provinserne Sivas, Konya eller Usak. De opdagede, at det var let at få beskæftigelse og arbejdstilladelse i Danmark og sendte, kraftigt opfordret af deres arbejdsgivere, besked hjem om, at der var masser af arbejde i Danmark. Snart ud- viklede der sig en omfattende kædevandring fra grupper af nærliggende landsbyer i de tre provinser. I etnisk henseende var gruppen fra Konya hovedsageligt kurdere, mens udvandrerne fra Sivas og Usak var tyrkere. Hvor massiv udvandringen var, blev påvist i 1970, hvor en optælling i en kurdisk udvandrerlandsby afslørede, at ca. 75\% af den mandlige befolkning mellem 18-55 år, i løbet af 3 år fra 1967-1970 var udvandret til Danmark og Vesttyskland (Hjarnø 1971; 1988; 1991).

Denne massive udvandring skyldes en kombination af faktorer. Eksistensgrundlaget i de landsbyer, hvorfra udvandringen er foregået, har været landbrug. Man havde siden midten af 1880erne privat ejendomsret til opdyrket jord, mens uopdyrkede arealer var en form for fælleseje. Traditionelt havde enhver ret til at opdyrke fællesjorden og få tilkendt ejendomsret til det areal, man opdyrkede. Det eneste formelle krav var, at man lod jorden registrere hos de lokale myndigheder, hvorefter man blev sat i skat. Jo flere sønner en husstand havde, jo flere hoveder kunne man sætte til at pløje ny jord op, og jo større bedrift kunne man få, og jo større muligheder havde man for at blive rig. Landbruget var primært baseret på kornavl kombineret med et mindre husdyrhold. Den økonomisk set vigtigste indtægtskilde var kornavlen (Hjarnø 1971; 1991).

Det var en produktionsform, der appellerede til at få mange sønner, og kombineret med udbredelsen af moderne medicin resulterede det $i$ en voldsom tilvækst i befolkningen. I årene efter Anden Verdenskrig oplevede man, især i årene under Koreakrigen, en høj pris på korn. Mangel på arbejdskraft førte til en begyndende mekanisering. I 1956 greb den tyrkiske regering ind og forbød opdyrkning af ny jord, fordi den voldsomme forøgelse af de opdyrkede arealer truede 
grundvandsressourcerne. Samtidig foretog myndighederne en kontrol af registreringen af de opdyrkede arealer. For at undgå ejendomsskatten havde mange undladt at lade store dele af deres jord registrere. Disse arealer blev konfiskeret og derpå benyttet som basis for en jordreform, som sikrede, at alle jordløse over 21 år, kvinder såvel som mænd, fik tildelt et areal. Herved blev alle over 21 år jordejere (Hjarnø 1971; 1991).

I de følgende år voksede folketallet. Kornavlen, som var den vigtigste økonomiske indtægtskilde, var imidlertid låst fast på grund af forbuddet mod opdyrkning af ny jord. Man forsøgte at udnytte overskuddet af arbejdskraft ved at slå om til mere udbytterige, men også mere arbejdskrævende afgrøder. Omlægningen var ikke tilstrækkelig til, at befolkningen kunne bibeholde deres hidtidige levestandard, og alternative muligheder for beskæftigelse uden for det traditionelle landsbyagerbrug var utilstrækkelige. I midten af 1960erne var der et udbredt ønske om udvandring. Det lykkedes enkelte at komme til Vesttyskland via den tyrkiske arbejdsformidling, som havde indgået aftale med Vesttyskland om eksport af arbejdskraft, men ventetiden for at blive udsendt var i midten af 1960erne vokset til 6-8 år (Hjarnø 1971).

Man befandt sig i en beklemt situation, og det er derfor forståeligt, at der kom gang i en massiv kædeudvandring til Danmark, så snart man opdagede, at det var let at få beskæftigelse og arbejdstilladelse i årene efter 1967. I takt med, at arbejdskraften udvandrede, blev de tilbageværende i stand til at mekanisere og overtage driften af udvandrernes jord. Ingen var interesseret $i$ at sælge deres jord. Man beholdt jorden og fik andre til at dyrke den, enten ved at man forpagtede den til andre eller, hvad der var mest almindeligt, man drev selv jorden, men betalte andre for at udføre arbejdet. Ud- vandrerne blev erstattet af moderne traktorer og mejetærskere. Selv om ca. $3 / 4$ af arbejdskraften udvandrede til Danmark og Vesttyskland i løbet af ganske få år, var der ikke noget fald i den lokale produktion. Udvandrernes arbejdspladser var erstattet af maskiner (Hjarnø 1971; 1991).

Alle udvandrerne ønskede at vende hjem og etablere sig som selvstændige. Nogle drømte om en tilværelse som landmænd og investerede $\mathrm{i}$ forbedring af deres bolig og staldbygninger hjemme i landsbyen samt i moderne teknologi, som fx traktorer. Mange var ivrige efter at købe jord i deres hjemlandsby, men ingen var i økonomisk nød, og alle holdt derfor fast i den jord, de ejede. Der var en del, der søgte at investere i handels- og transportsektoren. Udvandrernes hjemsendelser havde øget købekraften i landsbyen, men folk var blevet så velhavende, at de nu havde råd til at foretage en stor del af deres indkøb i de nærliggende storbyer. Dette resulterede bl.a. i, at nogle investerede i småbutikker i den nærliggende provinshovedstad Konya, som de fik pårørende til at passe. Nogle købte sig en lastbil eller bus og forsøgte sig som vognmænd. Konkurrencen var hård og mange måtte lukke. Enkelte investerede i boligbyggeri i de nærliggende provinshovedstæder, men på grund af den høje inflation gik mange fallit. Der var også et massivt engagement i eksport af traktorer, mejetærskere og brugte lastbiler fra Danmark til Tyrkiet. Udvandrerne havde mulighed for visse afgiftslettelser, hvis de indførte moderne maskineri, som de havde betalt med midler tjent i udlandet. Meget ofte tabte man på denne handel, fordi man ikke i tilstrækkelig grad tog højde for inflationen. Efterhånden indså flere og flere, at drømmen om hjemvenden var en myte (Hjarnø 1991).

I slutningen af 1970erne begyndte 
man familiesammenføringer, og de tog for alvor fart efter 1983 (Hjarnø 2000). Retten til familiesammenføring var frem til 1983 som nævnt betinget af, at den herhørende arbejder rådede over en passende bolig. Muligheder for at få en bolig, der levede op til kravene, var i det dyre, almennyttige boligbyggeri. Her var udskiftningen af lejere stor, og det gik forholdsvis hurtigt at blive berettiget til en bolig. Resultatet blev, at der opstod koncentrationer, efterhånden som flere og flere blev familiesammenført. Selv om huslejen var høj, var der ikke som i begyndelsen af 1970erne en klar økonomisk fordel ved at få sig en ejerbolig. Udbetalingerne på ejerboliger var steget, renten var høj, og der var ingen inflationsgevinster at hente. Derfor blev flertallet boende i det almennyttige.

I stedet for at satse på at skabe sig en fremtid som selverhvervende i hjemlandet voksede interessen for at blive selverhvervende i Danmark. Det var forholdsvis let at få lokaler til en butik, og kiosker og grøntforretninger dukkede op. 1960ernes omfattende udflytning fra de gamle arbejderkvarterer til nybyggeri i forstæderne havde ændret befolkningssammensætningen i de gamle centralt beliggende boligområder. Mange af de relativt købedygtige danske arbejderfamilier blev erstattet af unge studerende og arbejdsløshedsplagede danske og udenlandske familier, der ikke havde samme købekraft, som de der flyttede. Dette kombineret med en hård konkurrence fra bykernernes stormagasiner og det voksende antal supermarkeder slog mange af de lokale småbutikker ud. Mange lukkede eller kørte på pumperne, og det var relativt let for iværksætterlystne indvandrere at leje et tomt butikslokale eller overtage en lukningstruet butik ${ }^{11}$. Efterhånden gik man også i gang med andre brancher, såsom restauration, pizzeriaer, rejsebureauer mv. Sammenlignet med pa- kistanerne kom man i gang senere, og kapitalgrundlaget var ikke nær så stærkt. Man havde ingen friværdi i egen bolig, som man kunne kapitalisere i forbindelse med låntagning. Man var henvist til egne opsparinger, kontantlån hos nære slægtninge og venner af deres private opsparinger samt til mindre banklån, som undertiden var kautionslån. Enkelte har haft mulighed for at få iværksætterydelse, men mange har startet op på egen hånd.

I 1996 havde de selverhvervende mænd en gennemsnitlig skattepligtig bruttoindkomst på 380.000 kr., hvilket er væsentligt lavere end pakistanernes 540.000 kr. og danskernes 858.000 kr. (Hjarnø 2000).

\section{De danske eksjugoslavere}

Rekrutteringen af arbejdskraft fra det tidligere Jugoslavien var meget forskellig fra rekrutteringen af arbejdskraft fra Tyrkiet og Pakistan. Danske arbejdsgivere, især arbejdsgivere i metalindustrien, var i slutningen af 1960erne i akut nød for arbejdskraft. Da den danske regering i 1967 åbnede op for import af udenlandsk arbejdskraft, sendte en række virksomheder deres personalechefer af sted til det tidligere Jugoslavien for at hverve arbejdskraft. Man samarbejdede med de lokale arbejdsformidlingskontorer i Beograd, Skopje og Pristina og satsede meget bevidst på at rekruttere arbejdskraft, som havde erfaring med industriarbejde. I mange tilfælde sigtede man meget målrettet på at få arbejdskraft, der havde erfaring med metalarbejde, dvs. personer med erfaring i svejsning og smedning (Hjarmov et al 1996; Schierup 1988).

Det var hovedsageligt industriarbejdere, der kom til Danmark. Det var meget ofte individer, der havde en urban baggrund, idet de var opvokset i større eller mindre bysamfund. Mange var vokset op i hjem, hvor forældrenes eksistensgrundlag havde været baseret på lønar- 
bejde. For flertallet var motivet til at udvandre til Danmark at få et lønarbejde i Danmark, som kunne sikre en indkomst, så det var muligt at sende penge hjem. Flertallet forventede, at opholdet i Danmark var af midlertidig karakter, og man ville vende hjem, når mulighederne for at få lønnet beskæftigelse i hjemlandet blev bedre. Flertallet havde ikke som pakistanerne og tyrkerne nogen drøm om at vende hjem og skabe sig en tilværelse som selverhvervende. De opsparinger, man foretog, blev systematisk investeret $i$ at skabe forudsætninger for, at man kunne vende hjem til bedre materielle vilkår end dem man havde før udvandringen. Man brugte opsparingerne til at forbedre boligforholdene i hjemlandet og skaffe sig en række materielle forbrugsgoder i form bl.a. af hårde hvidevarer til de nye hjem, man opførte. Man købte fine personbiler og andre materielle symboler, der var tillagt stor prestige i de lønarbejdermiljøer, man kom fra.

Da krisen satte ind i 1970erne blev mange i gruppen ramt af arbejdsløshed i og med, at en række større virksomheder i metalindustrien måtte lukke - det var virksomheder som B\&W, Helsingør Skibsværft o.l. Trods lange perioder med arbejdsløshed er det kun et fătal, der i årenes løb har etableret sig som selverhvervende. Drømmen om at vende hjem var solidt forankret i mange, og det var først efter sammenbruddet af det tidligere Jugoslavien, at mange valgte at blive danske statsborgere (Hjarnø 2000).

Den specielle rekruttering af arbejdskraft til Danmark, der fandt sted i det tidligere Jugoslavien, fungerede som en sorteringsmaskine, der favoriserede individer med erfaring i lønnet industriarbejde, og som hovedsageligt var bærere af en lønarbejderbetonet livsform. De første indvandrere var hovedsageligt mænd, men der var også enkelte danske industrivirksomheder, som tog til det tidligere
Jugoslavien og hvervede kvindelig arbejdskraft. I visse tilfælde kom der en tilvandring af slægtninge og venner, men der opstod aldrig en massiv kædevandring, som den, der fandt sted blandt indvandrerne fra Pakistan og Tyrkiet. Industriarbejdere, som arbejderne fra det tidligere Jugoslavien, har ikke et stort landsbynetværk, som de kunne rekruttere arbejdskraft fra. De kom fra større og mindre byer, hvor husstandene har et socialt netværk, der i talmæssig henseende er relativt begrænset set $\mathrm{i}$ forhold til landsbybeboere i Tyrkiet og Pakistan.

I etnisk henseende er gruppen af indvandrere fra det tidligere Jugoslavien meget broget. De, der kom fra Serbien, var hovedsageligt medlemmer af det valachiske mindretal. De der kom fra Kosovo var for det meste albanere, mens de der kom fra Makedonien, hovedsageligt var makedonere eller albanere, men der er også repræsentanter fra enkelte andre etniske smågrupper.

Gruppen med oprindelse i det tidligere Jugoslavien har for flertallets vedkommende en anden livsformsprofil end grupperne med oprindelse i Pakistan og Tyrkiet. De er hovedsageligt bærere af en lønarbejderbetonet livsform. De relativt få selvstændige virksomheder, der forekommer, er ikke specielt etablerede med henblik på at tilfredsstille særlige behov for varer og tjenesteydelser blandt indvandrerne fra det tidligere Jugoslavien. De relativt få selverhvervende mænd havde i 1996 en gennemsnitlig skattepligtig bruttoindkomst på $214.000 \mathrm{kr}$. (Hjarnø 2000).

\section{Konklusion}

Sammenligningen mellem de tre indvandrergrupper viser, at der har været stor lighed mellem pakistanske og tyrkiske indvandreres sociale- og økonomiske baggrunde i erhvervsmæssig henseende, mens majoriteten af indvandrerne fra det 
tidligere Jugoslavien har en helt anden baggrund. Arbejdskraften fra det tidligere Jugoslavien blev specifikt rekrutteret, fordi den havde erfaring i industriarbejde. Det var individer, der var kendt med at være lønarbejdere. De var ofte opvokset i familier, hvis eksistensgrundlag var lønarbejde. Flertallet var bærere af lønarbejderlivsformen. Indvandrerne fra $\mathrm{Pa}$ kistan og Tyrkiet kom derimod hovedsageligt fra små rurale landsbysamfund, hvor deres forældre var selvstændige landmænd. De blev under deres opvækst præget af den selverhvervendes livsform og var ved indvandringen til Danmark bærere af denne livsform.

Motivet for udvandring var ens i alle tre grupper. Man ønskede at arbejde og tjene penge, så man kunne spare op og vende hjem. Der var imidlertid forskel på livsmålene, dvs. de mål som opsparingerne skulle bruges til. Hovedparten af indvandrerne fra Pakistan og Tyrkiet ønskede at vende hjem og etablere sig som selvstændige erhvervsdrivende, mens hovedparten af indvandrerne fra det tidligere Jugoslavien ikke nærede ønsker om at blive selverhvervende. De ville bruge deres opsparinger til at forbedre deres materielle kår i hjemlandet. De satsede på at vende hjem til et lønarbejde, som skulle give dem det daglige udkomme. Pengene, der blev tjent i udlandet, blev investeret i varige forbrugsgoder som nye boliger, hårde hvidevarer, personbiler o.l. Det er mål, som kan forventes af mennesker, der hovedsageligt er præget af en lønarbejderlivsform. De vil nyde livet, når de ikke er på arbejde.

For alle tre gruppers vedkommende har den strukturelle eller politiske udvikling i deres respektive hjemlande skabt solide barrierer for, at de kunne vende hjem og realisere deres livsmål. De er blevet i Danmark. Hvad indvandrerne med oprindelse i Pakistan angår, begyndte flere og flere i løbet af 1980erne og 1990er- ne at realisere deres livsdrøm om en tilværelse som selverhvervende ved at etablere sig i Danmark. Det samme skete for indvandrerne fra Tyrkiet, men af særlige grunde fastholdt de drømmen om at hjemvende noget længere end indvandrerne fra Pakistan. Livsformshypotesen synes at give en bekræftelse på den praksis i erhvervsvalg, man kan iagttage i de tre ovennævnte grupper.

Teorien om, at indvandring fra et bestemt område kan skabe et specifikt behov for særlige typer af varer og serviceydelser, som kan danne forudsætning for en etablering af selvstændige virksomheder og resultere $i$, at medlemmer i gruppen etablerer sig som selvstændige, selv om de ikke har tradition for at være selverhvervende, har ikke kunnet bekræftes ved at se på indvandrerne fra det tidligere Jugoslavien. De bor relativt koncentreret i bestemte områder i Danmark og har i lighed med indvandrere med oprindelse i Pakistan og Tyrkiet et behov for specielle varer og tjenesteydelser. Dette behov har ikke resulteret $i$, at medlemmer i grupperne af den grund har startet virksomheder. De virksomheder, jeg har talt med, og som drives af indvandrere med oprindelse i det tidligere Jugoslavien, har alle været rettet mod en bred kundekreds og ikke mod en specifik gruppe med oprindelse i det tidligere Jugoslavien. Når man ikke har søgt at dække disse behov gennem åbning af virksomheder, skyldes det at grupperne får disse behov dækket gennem andre indvandrergruppers eller danskeres virksomheder, at de lokale markeder er for små, eller at man fastholder sin traditionelle lønarbejderhabitus og ikke i tilstrækkelig grad er blevet motiveret til at ændre habitus. Der forekommer en klar mangel på interesse for at blive selvstændig hos flertallet, men det foreliggende datagrundlag kan ikke definitivt afkræfte enklaveøkonomiteoriens holdbarhed. 


\section{Noter}

1. Social og kulturel baggrund skal her forstås meget bredt og indbefatter bl.a. erhvervsmæssig, økonomisk, uddannelsesmæssig, sproglig, familiemæssig baggrund.

2. Enkelte forskere har fremsat den teori, at udelukkelse fra arbejdsmarkedet på grund af bl.a. diskrimination kan føre til selverhverv (Light 1979; Schierup 1993). Herved forklares overgang til selverhverv som et alternativ fx til arbejdsløshed. Det kan ikke udelukkes, at arbejdsløshed kan tvinge nogle til at forsøge at overleve ved at blive selverhvervende, men der er ingen pålidelig videnskabelig dokumentation, der kan bekræfte en systematisk sammenhæn mellem høj arbejdsløshed og høj andel, der bliver selverhvervende.

3. I visse udvandrersamfund kan der forekomme produktionsformer, der ikke er baserede på en kapitalistisk produktionsstrategi eller en simpel vareproduktionsstrategi. Her forekommer der andre livsformer. Som eksempel kan nævnes polynesiske indvandrergrupper i New Zealand (Hjarnø 1980).

4. De bosniske flygtninge er ikke medregnet.

5. Pladsen tillader ikke en detaljeret metodediskussion, i stedet henvises til Bourdieu 1972, 1999; Silverstein 1976; Daniel 1984.

Det kan nævnes, at økonomiske spørgsmål vedrørende finansiering og omsætning $\mathrm{i}$ den foreliggende problemstilling er følsomme emner, som ikke kan afdækkes pålideligt vha. de traditionelle formelle metoder.

6. Betingelserne for at opnå familiesammenføring er i årenes løb blev ændret i en mere og mere restriktiv retning, som der ikke vil blive redegjort for i denne sammenhæng.

7. I mange år var det en betingelse for at få arbejdstilladelse, at man var medlem af en arbejdsløshedskasse i de to første år.

8. Visse aktiviteter kræver fagkyndig specialviden. Man kan ikke åbne et skomagerværksted, hvis man ikke har lært at reparere sko eller kan ansætte en fagkyndig skomager.

9. Tallene giver ingen oplysning om ApS og A/S organiserede virksomheder. Flertallet af virksomheder ejet af indvandrere er organiseret som enkeltmandsejede virksomheder. Hvad talmaterialet i øvrigt angår kan man diskutere om opgørelsen, hvor antallet af selvstændige sættes i relation til antallet af aktive på arbejdsmarkedet, giver det mest præcise billede af udviklingen. Jeg har forsøgt at lave andre opgørelser, som har givet lidt andre resultater, men uanset hvordan jeg har vendt og drejet tallene, har det ikke ændret det generelle billede, som er, at pakistanerne startede tidligere med at blive selverhvervende i Danmark end indvandrerne fra Tyrkiet, samt at indvandrerne fra det tidligere Jugoslavien kun i meget begrænset omfang er blevet selvstændige. Der er et fald i de senere år som muligvis er knyttet til, at mange selverhvervende skifter nationalitet og bliver danske statsborgere. Jeg råder ikke over talmateriale der kan underbygge denne formodning. Indvandrere med oprindelse i Pakistan har længe været ivrige med at skifte statsborgerskab, mens indvandrerne fra Tyrkiet har været meget tilbageholdende. Indvandrerne fra det tidligere Jugoslavien gik først for alvor i gang med at blive danske statsborgere efter 1991. Talmaterialet spiller ikke en central rolle ud over, at det ser ud til at bekræfte det billede, jeg har dannet mig på basis af mine mange og årelange samtaler med medlemmer i de tre grupper.

10. "En passende bolig" blev ifølge Justisministeriets afgrænsning en selvstændig lejlighed, hvor der ikke er over 2 personer pr. beboelsesrum. Et enkelt værelse anses kun for passende for en person eller ægtefæller uden børn. To eller flere enkeltværelser uden selvstændigt køkken og toilet anses ikke for passende bolig for familier med børn.

11. Der er flere faktorer, som har medvirket til, at mange indvandrere har haft succes som selverhvervende: Ændringer i danskernes madlavnings- og spisevaner i retning af mere fastfood og eksotisk restaurationsmad har været godt for indvandrere med grillbarer og restaurationer. Den voksende interesse for eksotisk mad har været godt for de små detailbutikker. De lange åbningstider. En øget kvalitetsbevidsthed hos mange forbrugere for friske varer har utvivlsomt styrket de mange indvandrerejede grøntbutikker osv.

\section{Litteratur}

Aase, T. 1983: Arbeidsvandring og vedlikehold av landsbyøkonomi i pakistansk Punjab, Sosialantropologisk skriftserie no. 17. Bergen: Socialantropolo- 
gisk institutt.

Aase, T. 1991: Punjabi Practices of Migration, Social Anthropology, University of Bergen.

Anwar, M. 1996: British Pakistanis Demographic, Social and Economic Position. Warwick: Centre for research in ethnic relations.

Arbejdsmarkedsstyrelsen 1993: At møde barrierer, Rapport fra udvalg nedsat af arbejdsministeren vedrørende nedbrydning af barrierer for beskæftigelse af indvandrere og flygtninge.

Bager, T. \& Rezaei 2000: Immigrant businesses in Denmark: Captured in marginal business fields? Unpublished paper presented at the $11^{\text {th }}$ Nordic Conference on Small Business Research, Aarhus, Denmark, June $18^{\text {th }}$ $20^{\text {th }} 2000$.

Bajaj, K. \& Laursen, H.S. 1988: Pakistanske kvinder i Danmark: deres baggrund og tilpasning til det danske samfund. Esbjerg: Sydjysk Universitetsforlag.

Bonacich, E. 1973: "A theory of middleman minorities", American Sociological Review 38: 583-94.

Bonacich, E. 1993: "The other side of ethnic entrepreneurship: A dialogue with Waldinger, Aldrich, Ward and associates", International Migration Review 27 (3): 685-92.

Bourdieu, P. 1972: Outline of a Theory of Practice. Translated by Richard Nice. Cambridge: Cambridge University Press.

Bourdieu, P. 1990: The Logic of Practise, Cambridge: Polity Press.

Bourdieu, P. 1999: The Weight of the World: Social Suffering in Contemporary Society. Oxford: Polity Press.

Daniel, E.V. 1984: Fluid Signs.Berkeley \& Los Angeles: University of California Press.

Dokumentation om indvandrere nr. 1 1997: Minoritetsområdet, Mellemfolkeligt Samvirke.
Elverdam, B. 1991: Fra tradition til institution: Muslimske indvandrerkvinders møde med dansk hospital og praksislæge,. Islam i nutiden ; 8. Aarhus: Aarhus Universitetsforlag.

Friedman, J. 1994: Cultural Identity and Global Process, London: Sage.

Gudmundsson, E. \& G.F. Holten 1976: Pakistanere i Danmark, Forskningsrapport 79-3, Institut for Organisation, Handelshøjskolen i København.

Hjarnø, J. 1971: Fremmedarbejdere - en etnologiske undersøgelse af arbejdskrafteksportens virkninger $i$ Tyrkiet. København: Nationalmuseets Forlag.

Hjarnø, J. 1980: "Social Reproduction. Towards an understanding of aboriginal Samoa", Folk Vol. 21/22.: 23123.

Hjarnø, J. 1988: Indvandrere fra Tyrkiet $i$ Stockholm og København. Esbjerg: Sydjysk Universitetsforlag.

Hjarnø, J. 1991: Kurdiske indvandrere, Esbjerg: Sydjysk Universitetsforlag.

Hjarnø, J. 1996: Global cities in two ways A comment on Saskia Sassen's global city hypothesis. Esbjerg: South Jutland University Press.

Hjarnø, J. 1997: Copenhagen: On the Housing Battlefield. Esbjerg: South Jutland University Press.

Hjarnø, J. 2000: Indvandrernes levekår, upubliseret.

Hjarnø, J. 2001: Illegal Immigration and Developments in Employment in The Labour Markets of the EU, Aldershot: Ashgate.

Hjarnø, J. og T. Jensen 1997: Diskriminering af unge med indvandrerbaggrund ved jobsøgning. Esbjerg: Sydjysk Universitetsforlag.

Hjarmov, B., M. Fagerberg, M. Thomsen, 1996: “...måske er jeg en dansk jugoslav" - På vej mod en helhedsorienteret, flerkulturel vejledning, DTI Arbejdsliv. Arbejdsmarkedsstyrelsen. 
Højrup, T. 1983: Det glemte folk. Livsformer og centraldirigering, Hørsholm: SBI

Højrup, T. 1989: "Kulturanalyse og samfundsanalyse", NordNytt, vol. 37, 108-129.

Just Jeppesen, K. 1989: Unge indvandrere: En undersøgelse af andengeneration fra Jugaslavien, Tyrkiet og Pakistan. Rapport 89:6. København: Socialforskningsinstituttet.

Light, I. 1979: "Disadvantaged minorities in self-employment", The International Journal of Comparative Sociology 20: 31-45.

Light, I. \& B. Bonacich 1998: Immigrant Entrepreneurs: Koreans in Los Angeles, 1965-1982, Berkely, CA: University of California Press.

Light, I. \& C. Rosenstein 1995: Race, Ethnicity, and Entrepreneurship, New York: Russell Sage Foundation.

Morokvasic, M. 1993: "Immigrants in garment production in Paris and Berlin", in I. Light and P. Bhachu (eds), Immigration and Entrepreneurship: Culture, Capital, and Ethnic Networks, New brunswick and London: Transaction Publishers.

Phizacklea, A. 1990: Unpacking the Fashion Industry: Gender, Racism, and Class in Production, London: Routledge.
Rath, J. 1999: Immigrant business, unpublished paper.

Sassen, S. 1991: The Global City. New York, London, Tokyo. Princeton: Princeton University Press.

Sassen, S. 1994: Cities in a World Economy.Thousand Oaks: Pine Forge/Sage Press.

Schierup, C.-U. 1988: Integration? Indvandrere, kultur og samfund,. København: Billesø \& Baltzer.

Schierup, C.-U. 1993: På kulturens slagmark, Esbjerg: Sydjysk Universitetsforlag.

Schmidt, L.H. 1996: Indvandrere med egen forretning, Esbjerg, Sydjysk Universitetsforlag.

Silverstein, M. 1976: "Shofters, Linguistic Categories, and Cultural Description", Meaning in Anthropology, edited by Keith H. Basso and Henry A. Selby. Albuquerque: University of New Mexico Press.

Waldinger, R. 1993: "The two sides of ethnic entrepreneurship: Reply to Bonacich" International Migration Review 27 (3): 692-701.

Waldinger, R., H. Aldrich, R. Ward and Associates (eds.) 1990: Ethnic Entrepreneurs: Immigrant Business in Industrial Societies, London: Sage. 